\title{
1.. Apakah Liberalisasi Pendidikan Tinggi Meminggirkan Perguruan Tinggi Nasional?
}

\author{
Awan S. Dewanta
}

\begin{abstract}
In recent decades today it happens the changing of world economy orientation from manufacturing and sercive-based economies to knowledge based-economies. The main factor of the national economy building capacity is not only physical capital but also knowledge and technology. The science and technology become influenced factor for developing a nation. The higher education denotes institution that can produce the research of science, technology and educated human resources. In term of the copyright research products, the institutions and the universities in Indonesia are behind in the eastern Asian and Asean countries, for instances South Korea, Taiwan, and Sincapore. These courtries have shown the qualities in developing science and they become the competitor of advanced countries.
\end{abstract}

Katā Kunci: sains, pendidikan, liberalisasi, teknologi

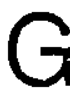
elombang giobalisasi dan kemajuan iteknologi saat ini telah memaksa pemerintahan di masing-masing negara mengambil kebijakan membuka pasar dan melakukan liberalisasi perdagangan barang dan jasa, termasuk pula jasa pendidikan tinggi. Kemajuan teknologi komunikasi dan komputer telah memungkinkan mobilitas barang dan jasa melintasi batas antar negara tanpa hambatan. Barang dan jasa, yang diproduksi oleh negara yang sangat jauh, dapat dinikmati bersama-sama dengan barang dan jasa yang diproduksi oleh masyarakat kita sendiri. Demikian pula, produk jasa pendidikan tinggi, yang diproduksi oieh institusi yang sangat jauh jaraknya, dapat diakses di sini. General Agreement on Trade in Services (GATS) dalam World Trade Organization (WTO) belum mengatur sepenuhnya regulasi perdagangan jasa pendidikan tinggi.
Sementara ini, produk jasa pendidikan tinggi disamakan dengan produk jasa lainnya sehinggga jasa pendidikan tinggi ini dapat diperdagangkan secara bebas melintasi batas negara. Produk jasa pendidikan tinggi ini dapat ditawarkan melalui "dunia maya" dan dapat diaksesoleh siapa saja, tanpa terikat oleh eknis, gender, agama, ataupun status sosial. Bahkan, kecanggihan teknologi komunikasi dan komputer ini telah banyak dipergunakan untuk meningkatkan akses pendidikan di daerah-daerah terisolasi, sebagaimana slogan bank dunia: Education for All.

Bagaimanakah dengan perguruan tinggi nasional menghadapi globalisasi dan liberalisasi perdagangan jasa pendidikan tinggi? Apakah perguruan tinggi nasional menjadi menjadi terpinggirkan oleh kehadiran perguruan tinggi asing? Ataukah liberalisasi pendidikan tinggi ini meningkatkan mutu perguruan tinggi nasional melalui spillover effect? 


\section{Kondisi Pendidikan Tinggi Nasional}

Pada saat ini tengah terjadi perubahan orentasi ekonomi dunia dari mánufacturing and service-based economies ke knowledge-based economies. Faktor utama pembangunan kapasitas (ekonomi) nasional tidak lagi physical capital, tetapi knowledge. IImu pengetahuan dan teknologi merupakan faktor penentu bagi keberhasilan pembangunan suatu bangsa. Bagaimana kondisi iptek di Indonesia?

Perguruan tinggi merupakan lembaga/ institusi yang menghasilkan produk berupa riset Iptek (llmu Pengetahuan dan Teknologi) dan tenaga kerja terdidik. Dalam produk riset Iptek yang dipatenkan, lembaga riset dan perguruan tinggi di Indonesia mengalami ketertinggalan dibandingkan negara-negara Asia Timur. Negara Korea Selatan, Taiwan, dan Singapora telah menunjukkan kualitasnya dalam mengembangkan ilmu pengetahuan dan bersaing dengan negara maju (Gambar 1).

\section{Gambar 1. Sebaran Hak Patent International}

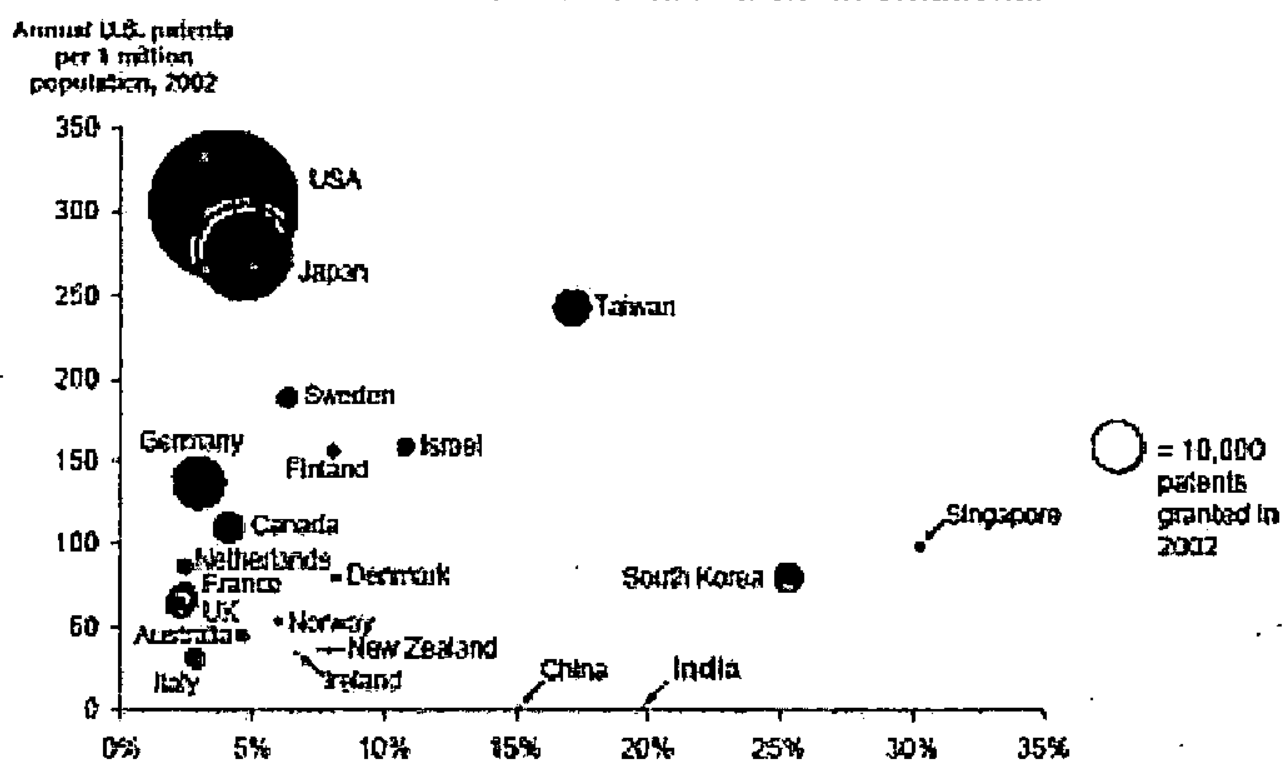

Rendahnya kemampuan perguruantinggi . menghasilkan penelitian iptek tersebut mungkin masih dapat diterima karena . perguruan tinggi di indonesia, sebagai negara berkembang, masih menekankan aspek pengajaran ketimbang penelitian. Tetapi toleransi tersebut perlu dibatasi karena kita hidup di era global. Kemajuan, yang dicapai oleh bangsa, akan tetap kalah apabila kemajuan yang dicapai tersebut masih kalah cepat dibandingkan dengan bangsa lain. Dalam analogi di bidang olah raga, pengembangan Iptek olah raga bulutangkis di Indonesia saat ini sudah lebih maju dibandingkan dengan masa lalu, tetapi pengembangan Iptek olah raga bulutangkis di negara lain lebih cepat dibandingkan dengan negara kita dengan bukti semakin redupnya prestasi bulutangkis Indonesia di pentas dunia.

Bila pendidikan tinggi nasional menekankan aspek pengajaran, bagaimana dengan produk tenaga kerja terdidik yang dihasilkannya? Produk tenaga kerja terdidik, 
yang dihasilkan, juga kurang bermutu dibandingkan produk tenaga kerja di negara lain. Kinerja daya saing global tertinggi di tahun 2005 ditunjukkan oleh negara Finlandia' , Amerika Sertikat, Swedia, Denmark, Taiwan, Singapura, dan Iceland. Negara-negara tersebut menempati ranking 1-7 dari global competitiveness index ( $\mathrm{GCl}$ ) yang dikeluarkan World Economic Forum. Penyebaran ranking $\mathrm{GDl}^{2}$ secara global ditunjukkan dengan gambar 2 . Indonesia mengalami penurunan daya saing dari ranking 69 (2004) menjadi ranking 74 (2005) dengan nilai 3,53.

Oleh karena Indonesia termasuk labor abundant dalam perdagangan internasional, maka rendahnya daya saing tersebut disebabkan oleh rendahnya produktivitas tenaga kerja. Dengan kata lain, pendidikan nasional kita belum mampu memproduksi tenaga kerja yang produktif dan kreatif. Akibat langsung dari rendahnya produktifitas faktor tenaga kerja tersebut, negara Indonesia kurang diminati oleh investor asing, yang ditunjukkan oleh rendahnya aliran investasi asing langsung (FDI). Dalam perbandingan, produktifitas tenaga kerja Indonesia setara dengan tenaga kerja di $\mathrm{Pa}$ kistan, dan kalah jauh dengan Cina, Korea, Taiwan, Malaysia, Singapore, dan India (gambar 3). Demikian juga, minat penanaman modal investor asing di Indonesia relatif rendah dibandingkan negara lain yang berada di kawasan Asia Tenggara dan Asia Timur (gambar 4).

Rendahnyakemampuanmengembangkan Iptek saat ini semakin diperburuk lagi dengan rendahnya human capital stock yang dimiliki oleh Indonesia di masa depan. Laporan IEA (Intemational Association for Education Achievement), yang dikutip World Bank, melaporkan bahwa: (1) kemampuan bacaanakSD dinegaranegara Asia Timur adalah rendah, yaitu 75.5 (Hongkong), 74.0(Singapura), 65.1 (Thailand),
52.6 (Pilipina), dan 51.7 (Indonesia); dan (2) PelajarSD Indonesia hanya mampu menyerap $30 \%$ materipelajaran dan mengalami kesulitan dalam menjawab pertanyaan yang membutuhkan jawaban yang komprehensip. Hal yang senada ditunjukkan oleh data TIMSSEvaluation centre, research and development centre, (World Bank, 2003). Data tersebut menjelaskan bahwa kemampuan pelajar Indonesia dalam bidang matematika dan sain berada di bawah rata-rata intemasional. Pelajar Indonesia berada di ranking 34 (untuk bidang matematika) dan 32 (untuk sain). Ranking tersebut memang masih lebih tinggi dibandingkan dengan pelajar di Chile, Pilipina, Maroko, dan Afrika Selatan, tetap lebih rendah dibandingkan dengan pelajar di Singapura, $\mathrm{Ma}$ laysia, dan Thailand. Hal ini memberikan indikasi bahwa peningkatan mutu pelajar di Indonesia kalah cepat dengan rekannya yang berada di kawasan Asia, dan berarti pula persedian sumberdayamanusiaterdidikmasa depan relatif terbatas dibandingkan negara lain.

Upaya awal peningkatan mutu pendidikan nasional telah dilakukan oleh Departemen Pendidikan Nasional dengan ditetapkannya UU No. 20 Tahun 2003 tentang Sistem Pendidikan Nasional (Sisdiknas) dan UU No. 14 Tahun 2005 tentang Guru dan Dosen. Kualifikasi tenaga pendidik diatur dalam pasal 42 UU No.20 Tahun 2003 ayat 1 , yang berbunyi: "Pendidik harus memiliki

1 Kesuksesan negara Finlandia dalam persaingan global ditunjang oleh teknologi informasi dan telekomunikasi (Dahiman, 2006)

2 Indeks daya saing global merupakan penjumlahan dari indeks daya saing bisnis (Business Competitiveness) dan ekonomi (Growth Competitiveness). Kedua indeks tersebut disusun dari 9 komponene penilaian, yaitu institusi, infrastruktur, makro-ekonomi, kesehatan dan pendidikan dasar, pendidikan tinggi dan training, efisiensi pasar, teknologi, kecanggihan bisnis, dan inovasi. 
Gambar 2. Sebaran Indeks Daya Saing Global; 2005

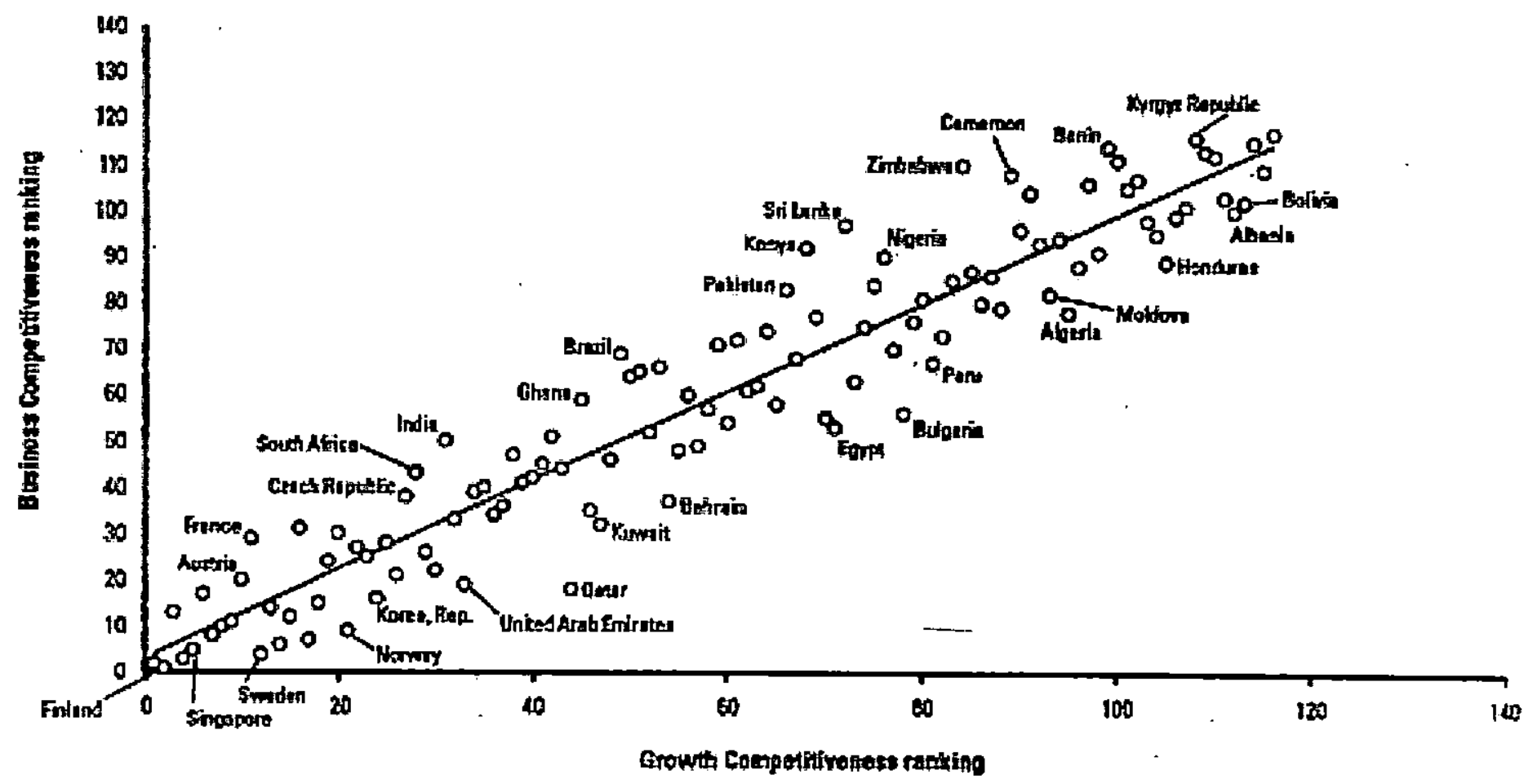


Topik: Globalisasi dan Liberalisasi dalam Bidang Pendidikan

kualifikasi minimum dan sertifikasi sesuai sehat jasmani dan rohani, serta memiliki dengan jenjang kewenangan mengajar, kemampuan untuk mewujudkan tujuan

Gambar 3. Sebaran Kinerja Produktivitas Tenaga Kerja, 2002

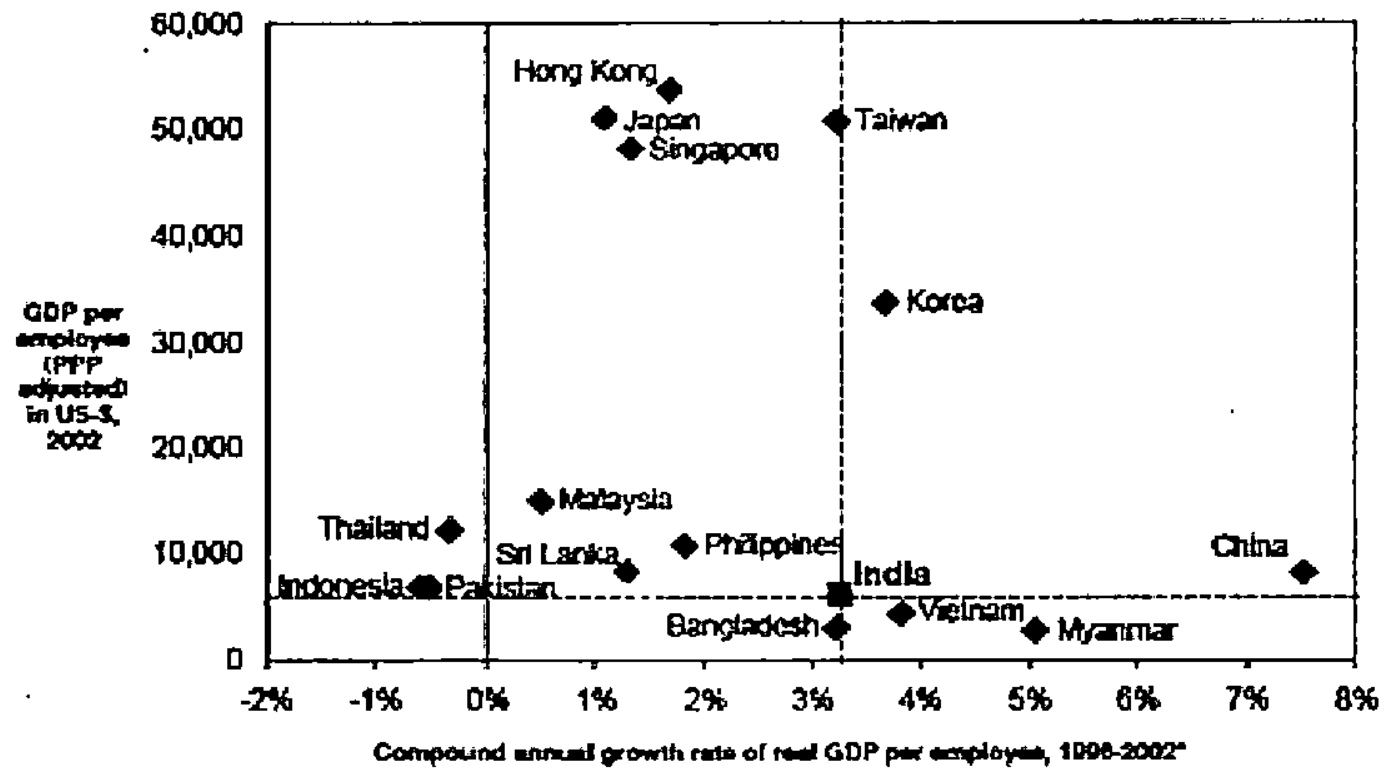

Sumber: EIU, 2003

Gambar 4. Sebaran Foreign Direct Investment, 2002

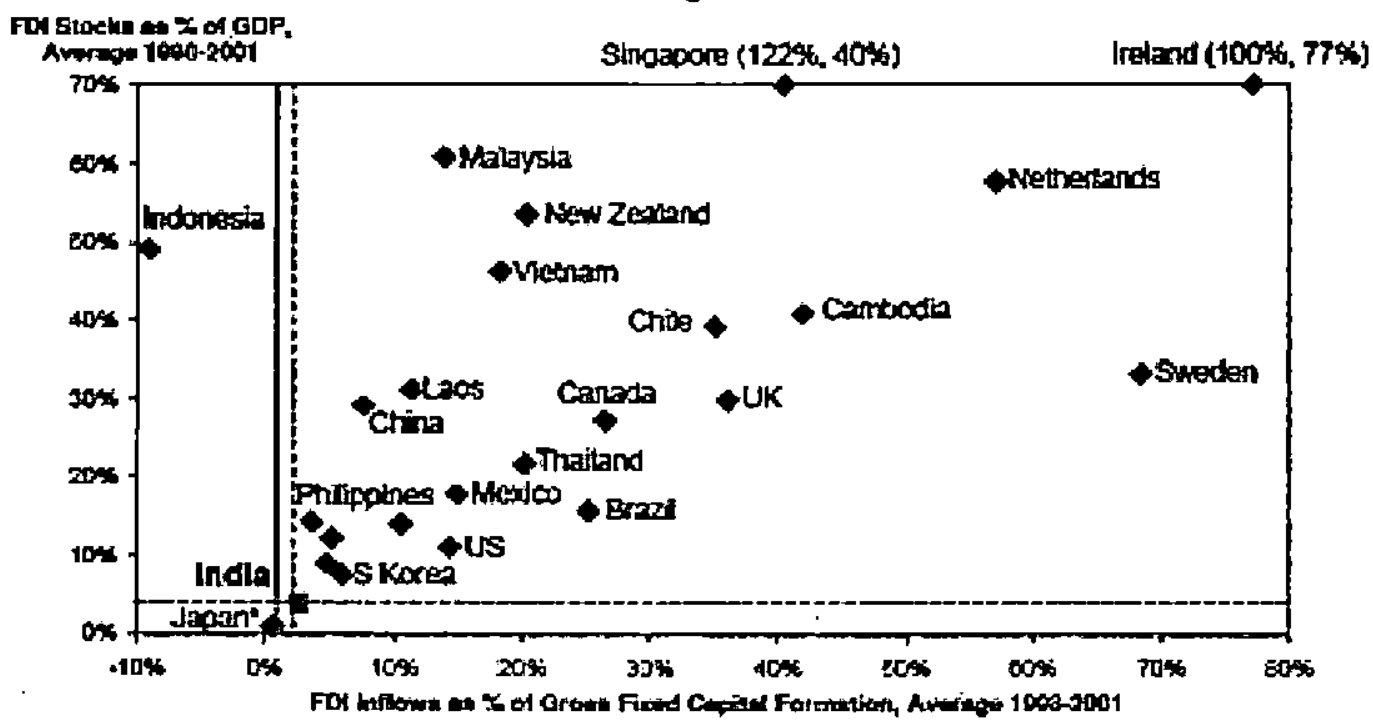

Sumber: World Investment Report, 2002 
pendidikan nasional", dan dilanjutkan pada ayat 2: "Pendidik untuk pendidikan formal pada jenjang pendidikan usia dini, pendidikan dasar, pendidikan menengah, dan pendidikan tinggi dihasilkan oleh perguruan tinggi yang terakreditasi". Penegasan peningkatan kua-litas guru ditegaskan kembali pada Pasal 8 dan 9 UU No.14 Tahun 2005 yang menya-takan: "Guru wajib memiliki kualifikasi akademik, kompetensi, sertifikat pendidik, sehat jasmani dan rohani, serta memiliki kemampuan untuk mewujudkan tujuan pendidikan nasional" dan "Kualifikasi akademik sebagaimana dimaksud dalam Pasal 8 diperoleh melalui pendidikan tinggi program sarjana atau program diploma empat". Upaya awal tersebut perlu didukung dan tindak lanjuti oleh berbagai kebijakan dan strategi yang tepat, nyata dan komprehensif, karena kita sudah semakin tertinggal dibandingkan negara berkembang lainnya.

\section{WTO dan Liberalisasi Pendidikan Tinggi}

Dampak liberalisasi industri pendidikan tinggi di negara berkembang masih menjadi polemik dan perdebatan. Sementara ini, liberalisasi pendidikan tinggi dalam WTO melalui GATS belum secara terperinci diatur. Produk industri perguruan tinggi dianggap sama dengan komoditi lainnya yang dapat bebas diperdagangkan. Argumen yang dikemukakan adalah perdagangan bebas akan meningkatkan kemakmuran dan kesejahteraan bersama karena jasa pendidikan tinggi akan menimbulkan spillover effect yang berupa percepatan technological catch-up.dan technological diffusion (Bloom, 2005).

Pertanyaan berikutnya, apakah perdagangan jasa pendidikan tinggi dapat disamakan dengan perdagangan barangseperti mobil atau pisang atau dapat disamakan dengan komoditas jasa telekomunikasi? Pengaturan dan kontrol terhadap perdagangan jasa pendidikan tinggi masih mendapatkan kesulitan untuk dirumuskan oleh GATS dalam WTO. Liberalisasi jasa pendidikan tinggi ini mempunyai kaitan erat dengan TRIPS (Trade Related Intellectual Property yang merupakan bentuk pengaturan dan proteksi hak cipta. Liberalisasi perdagangan jasa pendidikan tidak dapat dilepaskan oleh proteksi hak cipta pemilik produk jasa pendidikan tinggi, sebagaimana produk jasa keuangan ataupun asuransi. Proteksi hak cipta ini akan memberikan perlindungan perguruan tingginasional terhadap perguruan tinggi asing. Permasalahannya, bagaimana merumuskan bentuk-bentuk produk jasa pendidikan apa saja yang dapat dipatenkan? Dengan adanya hak paten ini, penyelenggara pendidikan tinggi nasional akan mendapat perlindungan dan proteksi. Selain itu, liberalisasi pendidikan tinggi yang telah berlangsung saat ini belum mendapatkan dukungan dari departemen pendidikan di banyak negara maju, seperti Amerika dan Inggris ${ }^{3}$. Pihak-pihak yang berkepentingan dengan liberalisasi pendidikan tinggi datang dari penerbit multinasional, teknologi informasi, perusahaan komputer, penyedia sistem pendidikan jarak jauh (seperti: Sylvan Leaming Systems), dan bisnis pendidikan global (Altbach, 2004). Kepentingan mereka didukung oleh departemen perdagangan untuk meningkatkan pendapatan dan promosi ekspor.

Asosiasi lembaga pendidikan di Amerika, Canada, dan negara maju lainnya

3 Dukungan liberalisasi pendidikan tinggi di Amerika dan Inggris berasal dari Department of Commerce (Amerika Serikat) dan Department of Trade and Industry (United Kingdom). 
masih bersikap skeptis dan menentang liberalisasi pendidikan tinggi. American Council on Education, yang merupakan representasi pemimpin-pemimpin universitas besar, di Amerika, menyatakan ketidaksetujuan terhadap liberalisasi pendidikan tinggi karena negara berkembang belum mempunyai kesiapan konsep perdagangan bebas atas produk pendidikan dan ilmu pengetahuan. Negara berkembang belum mempunyai produk jasa pendidikan tinggi yang dapat di ekspor. Lebih jauh, Lawrence Summers, president of Harvard University dan mantan U.S. treasury secretary, mengatakan:

Òl'm skeptical as to whether bringing educational issues under the auspices of trade negotiations would be helpful... To start with, many educational institutions is non-profit, their motivations are different from the motivations of commercial firms that we think of in a trade context. There may be some egregious practices that should be addressed, but I would be skeptical about treating education in a way that had any parallels with financial services, with insurance, or with foreign investments"

Dalam pernyataan resmi yang dikeluarkan, WTO memberikan kebebasan masing-masing pemerintah untuk memilih perdagangan produkjasa apayang akan dibuka akses pasarnya dan selaraskan dengan agenda pembangunan nasionalnya. Masingmasing anggota WTO tidak mempunyai kewajiban membuka akses pasar bagi produk jasa asing tanpa memberikan garansi bahwa produkjasa domestikmampu bersaing. Secara lebih detail, WTO mengatakan:

There is no obligation on any WTO Member to allow foreign supply of any particular service - nor even to guarantee domestic competition, since it is possible to maintain a monopoly supplier, whether public or private, of any service.
Governments are free to choose those services on which they will make commitments guaranteeing access to foreign suppliers. Each Member must have a national schedule of commitments, but there is no rule as to how extensive it should be. Some least-developed Members have made commitments only on tourism, for example, and in general there is great variation in the coverage of schedules, reflecting national policy objectives and levels of economic development. There is agreement among all Governments that in the new round of negotiations the freedom to decide whether to liberalize any given service and the principle of progressive liberalization will be maintained (WTO, 2005)

Hal ini menunjukkan bahwa liberalisasi pendidikan tinggi tidak dapat disamakan dengan liberalisasi keuangan. Pengaturan dan kontrol terhadap copyright dan patent pendidikan tinggi belum dapat disepakati dan masih mendapatkan kesulitan dalam perumusannya. Sementara ini, Indonesia, sebagaimana negara berkembang lainnya, menjadi importir dan masih jauh untuk menjadi eksportir produk jasa pendidikan tinggi. Hal ini merupakan bentuk ketimpangan perdagangan, dan bukan tujuan perdagangan bebas sebagai sarana menuju kemakmuran bersama.

\section{Pengalaman dan Model Kebijakan}

inovasi pendidikan transnasional, seperti pendidikan jarak jauh berdasarkan internet, kampus cabang, "franchising" pendidikan, merupakan peluang dan tantangan bagi pelajar untuk mendapatkan pendidikan terbaikyang dapat diperolehnya. Hal ini memunculkan dilema bagi penyelenggara jasa pendidikan tinggi nasional. Penyelenggara jasa pendidikan 
tinggi nasional mendapatkan tantangan persaingan yang semakin berat, bahkan tidak mungkin akan menjadi pihak yang kalah dalam "game" persaingan industri pendidikan tinggi.

Bagaimana dengan pengalaman negara India meningkatkan mutu dan membuka (sebagian) akses pendidikan tinggi asing? India adalah negara miskin. Berdasarkan United Nation tahun 2003, pendapatan perKapita India, yang sebesar $\$ 555$, lebih rendah dibandingkan pendapatan per Kapita Indonesia yang sebesar \$ 944. Tetapi, rendahnya pendapatan perKapita India tersebut tidak berarti tingkat pendidikan In- dia lebih rendah dibandingkan Indonesia. Beberapa perbandingan capaian pendidikan antara Indonesia dan India ditunjukkan dengan tabel 3 , sedangkan perbadingan capaian pendidikan tinggi antara Indonesia dan India ditunjukkan dengan tabel 4. Pada tabel 3 , kinerja pendidikan di Indonesia relatif lebih baik dibandingkan kinerja pendidikan di India, tetapi dalam pendidikan tinggi di india menjadi relatif lebih baik dibandingkan di Indonesia. Pada tabel 4, negara India menempatkan 3 perguruan tinggi di 1000 besar perguruan tinggi dunia, yaitu Indian Institute of Science Bangalore (660), Indian Institute of Technology (858), dan Indian In

Tabel 3. Capaian Pendidikan di India dan Indonesia

\begin{tabular}{|c|c|c|}
\hline Items & India & $\begin{array}{l}\text { Indo- } \\
\text { nesia }\end{array}$ \\
\hline Literacy Rate, Ages 15-24, 2000-04, Female (\%) & 67 & 98 \\
\hline Literacy Rate, Ages 15-24, 2000-04, Male (\%) & 81 & 99 \\
\hline Literate Women as \% of Literate Men, Ages $15-24,2000-04$ & 81 & 99 \\
\hline Literacy Rate, 15 Years and Over (\%), Female, 2000 & 45 & 82 \\
\hline Literacy Rate, 15 Years and Over (\%), Male, 2000 & 68 & 92 \\
\hline Women Who Have Completed Fifth Grade, Poorest Fifth (\%) & 10 & 52 \\
\hline Women Who Have Completed Fifth Grade, Middle Fifth (\%) & 37 & 67 \\
\hline Women Who Have Completed Fifth Grade, Richest Fifth (\%) & 86 & 92 \\
\hline $\begin{array}{l}\text { Gross Pre-Primary School Enrollment Ratio, Female (\%), } \\
2000\end{array}$ & 20 & 19 \\
\hline Gross Pre-Primary School Enrollment Ratio, Male (\%), 2000 & 20 & 18 \\
\hline Gross Primary School Enrollment Ratio (\%), Female, 2000 & 92 & 109 \\
\hline Gross Primary School Enroliment Ratio (\%), Male, 2000 & 111 & 111 \\
\hline Gross Secondary School Enrollment Ratio, Female (\%), 2000 & 40 & 56 \\
\hline Gross Secondary School Enrollment Ratio, Male (\%), 2000 & 57 & 58 \\
\hline Gross Tertiary School Enrollment Ratio (\%), Female, 2000 & 8 & 13 \\
\hline Gross Tertiary School Enrollment Ratio (\%), Male, 2000 & 13 & 16 \\
\hline $\begin{array}{l}\text { Pupils Starting Grade } 1 \text { who Reach Grade } 5(\%) \text {. Female. } \\
2000\end{array}$ & 65 & 100 \\
\hline Pupils Starting Grade 1 who Reach Grade 5 (\%). Male. 2000 & 70 & 92 \\
\hline
\end{tabular}

Sumber: Asian Development Bank (ADB), 2003 dan Population Reference Bureau, 2006. 
Topik: Globalisasi dan Liberalisasi dalan Bidang Pendidikan

Tabel 4. Ranking Universitas Terkemuka Menurut Negara, 2005

\begin{tabular}{|l|l|c|c|}
\hline RANK & \multicolumn{1}{|c|}{ CoUNTRY } & Top 200 & Top 1000 \\
\hline 1 & United States of America & 110 & 455 \\
\hline 2 & Canada & 19 & 42 \\
\hline 3 & Germany & 16 & 68 \\
\hline 4 & United Kingdom & 13 & 79 \\
\hline 5 & Australia & 6 & 32 \\
\hline 9 & Japan & 4 & 24 \\
\hline 11 & Brazil & 2 & 11 \\
\hline 14 & Taiwan & 1 & 14 \\
\hline 19 & Mexico & 1 & 4 \\
\hline 20 & Singapore & 1 & 2 \\
\hline 25 & China & & 9 \\
\hline 28 & Hong Kong & & 6 \\
\hline 32 & Thailand & & 6 \\
\hline 34 & Korea Republic Of & & 4 \\
\hline 36 & India & & 3 \\
\hline 39 & Chile & & 2 \\
\hline 42 & Argentina & & 1 \\
\hline 50 & Indonesia & & 1 \\
\hline
\end{tabular}

Sumber: Webometrics Ranking of world Universities, 2006

stitute of Technology Kanpur(999), sedang Indonesia hanya menempatkan Institute Teknologi Bandung pada urutan ke 707.

Mengapa pendidikán tinggi di India relatif lebih baik? Pemerintah India melakukan tiga strategi utama. Pertama, beberapa perguruan tinggi di India melakukan kerjasama dengan perguruan tinggi terkemuka baik di negara maju, seperti: $n$ dian Institutes of Technology yang bekerjasama dengan Massachusetts Institute of Technology dan Indian Institutes of Management yang mempunyai hubungan erat dengan Harvard Business School, disamping mengiriman pelajar India untuk bersekolah di luar negeri. Kerjasama antara perguruan tinggi India dengan perguruan tinggi di negar maju meliputi donor, dosen tamu mengajar di India, pengiriman dosen
India untuk melakukan training dan postdoctoral, bantuan peralatan laboratorium modern dan bantuan fasilitas.

Kedua, melakukan kolaborasi saling menguntungkan antara industri dan universitas yang meliputi bidang teknik, management dan komputer. Perkembangan perusahaan multi-nasional di India mendorong pihak universitas-universitas $\mathrm{di}$ India untuk menciptakan teknologi tinggi bagi India. Kerjama tersebut meliputi penyusunan kurikulum, bantuan peralatan, training pengajar, beasiswa mahasiswa, dan pembiayaan penelitian. Perusahaan global, seperti General Electric dan Lucent Technologies, memberikan beasiswa bagi mahasiswa India untuk mendalami bidang teknik yang akan dikembangkan di india. 
Ketiga, Kerjasama erat antara universitas-universitas di India dengan negara lain. Kerjasama antar universitas yang dilakukan oleh India tidak hanya terbatas dengan universitas negara maju. Universitas India melakukan kerjasama dengan pemerintah Thailand dan Amerika dalam membangun "match-making service" berbasis internet. Dalam proyek JUNO (Joint Universities Network Online), universitas-universitas India dan Thailand, melakukan eksplorasi potensi untuk melakukan pertukaran mahasiswa, pertukaran staf pengajar, kerjasama kurikulum, dan penelitian-penelitian yang dibutuhkan oleh counterpart Amerika. Kerjasama antar universitas tersebut juga melakukan kerjasama bi-lateral scholarly exchange programs, yang disponsori oleh: Fulbright, $D A A D$, dan the British Council; memungkinkan membuka progam studi baru dan program kegiatan antara universitas tempat kuliah dengan universitas asal penerima beasiswa.

Model kebijakan pendidikan tinggi di India tersebut bukan berarti paling baik, karena masing-masing negara memiliki perbedaan karakteristik dan agenda pengembangan pendidikan tinggi. Secara umum, model-model kebijakan pendidikan tinggi antara lain adalah:

\section{Specific government efforts to regulate, but not stifle, free- market trends}

Pemerintah mendorong universitas swasta untuk berkembang dan melakukan diversifikasi pendidikan tinggi, meskipun pemerintah tetap mempunyai otoritas melakukan intervensi dalam pemerataan akses pendidikan, prosedur akreditasi, kurikulum, dan muatan budaya nasional. Strategi ini dilakukan oleh pemerintah Malaysia.

\section{New contracts with previously centralized authority}

Pemerintah menawarkan kontrak kepada pengelola pendidikan tinggi negeri untuk mengelola sendiri keuangan, akademik, dan staf pengajar yang dibutuhkan, meskipun target yang harus dicapai ditetapkan oleh pemerintah. Strategi ini dilakukan oleh pemerintah New Zealand, dan Perancis.

\section{Quality assurance models}

Pemerintah melakukan reformasi pendidikan tinggi secara komprehensif. Tugas pemerintah melakukan pengawasan dan standarisasi kualitas lulusan pendidikan tinggi. Sebagai contoh:

- Pemerintah Brazil menerapkan empat komponen standarisasi, yaitu ujian nasional pendidikan tinggi untuk melakukan validasi materi ajar dan akreditasi institusi; evaluasi program pendidikan tinggi; akredikasi program pendidikan tinggi jarak jauh; dan intergrasi sistem dan informasi pendidikan.

- Pemerintah SAR-HongKong membentuk the Hong Kong Council of Academic Accreditation (HKCAA) yang bertanggungjawab terhadap penetapan kualitas, penetapan akreditasi, dan pelaksanaannya, serta memberikan rekomendasi bagi peningkatan kualitas pendidikan tinggi. Evaluasi dan akreditasi yang dilakukan HKCAA ini juga diberlakukan bagi program pendidikan tinggi asing.

\section{Regulating new private providers}

Pemerintah mendorong pendirian lembaga pendidikan tinggi swasta baru. Menteri pendidikan menjadi penagung-jawab 
utama dan memiliki otoritas penuh untuk melakukan kontral dan menetapkan peraturan pelaksanaan penyelenggaraan pendidikan tinggi. Strategi ini dilakukan oleh pemerintah Uruguay.

\section{Virtual and computer-based dis- tance learning models from di- verse countries}

Pemerintah mendorong penggunaan komputer dan meningkatan akses pendidikan tinggi dengan program pendidikan tinggi jarak jauh. Program pendidikan tinggi jarak jauh ini memanfaatkan teknologi komputer dan telekomunikasi. Pemerintah yang telah mengġunakan model kebijakan ini, antara lain:

- Pemerintah Vietnam memberikan izin kepada universitas Australian mendirikan "virtual university" yang bernama Australia's R.M.I.T. International University Vietnam;

- University of the Highlands and Islands membuka "virtual university" di pedesaan untuk mengurangi biaya dan keterbatasan pengajar;

- Dr. B. R. AmbedkarOpen University (India) menawarkan pendidikan tinggi jarak jauh dengan kualifikasi yang lebih ringan dan ditujukan untuk meningkatkan partisipasi wanita dalam pendidikan tinggi; dan

- African Virtual University, yang merupakan pilot project dari the World Bank, menawarkan pendidikan tinggi lintas batas benua untuk menjangkau daerah terisolasi, buruknya intrastruktur transportasi, dan kendala jarak.

\section{Penutup}

Pendidikan tinggi nasional belum mampu menghasilkan produk iptek dan tenaga kerja terdidik yang trampil.dan kreatif. Liberalisasi pendidikan tinggi perlu kehati- hatian dan banyak model kerjasama yang dapat dipilih dengan mempertimbang agenda pembangunan nasional dan minimumisasi dampak negatif bagi pendidikan tinggi nasional. Liberalisasi pendidikan tinggi, yang tidak hati-hati, akan berakibat buruk bagi lembaga pendidikan tinggi nasional. Lembaga pendidikan tinggi nasional tidak mendapat technological spillover dari liberalisasi pendidikan tinggi, tetapi justru akan dipinggirkan oleh kehadiran lembaga pendidikan tinggi asing. Kerjasama saling menguntungkan antara antara lembaga pendidikan tinggi nasional dan asing merupakan jalan tengah yang dapat ditawarkan.

Kerjasama tersebut dimulai dari kebutuhan pendidikan tinggi yang paling urgen yang belum dapat dipenuhi oleh lembaga pendidikan tinggi nasional, dilaksanakan secara komprehensif ${ }^{4}$, dan tidak menomorsatukan pertimbangan ekonomi. Urgenitas kebutuhan pendidikan tinggi, yang belum dapat dipenuhi, tidak identik dengan keuntungan bisnis jangka pendek yang diperoleh. Peningkatan kuantitas sumber daya manusia yang berkualitas juga merupakan keuntungan bisnis meskipun keuntungan bisnis tersebut baru dinikmati dalam jangka panjang, sebagaimana keuntungan bisnis saat ini yang diperoleh negara-negara Asia Timur dan Singapura merupakan hasil investasi human capitalyang dilakukan pada 20 tahun yang lalu.

${ }^{4}$ Untuk meningkatkan perluasan dan pemerataan akses pendidikan nasional, pemerintah membuka virtual university. Pembukaan virtual university ini perlu didukung oleh murahnya biaya telekomunikasi, internet, harga komputer. Kebijakan pendidikan tidak efektif bila tidak didukung oleh kebijakan lain diluar wewenang dan otoritas Menteri Pendidikan. 


\section{Daftar Pustaka}

Altbach, Philip G., 2004. "Globalization and The University: Myths and Realities in an Unequal World", Tertiary Education and Management Paper, Boston College: Center for International Higher Education.

Bloom, David., David Canning, dan Kevin Chan, 2005. "Higher Education and Economic Development in Africa", Paper in World Bank Seminar, Harvard University.

Chen, Derek H. C. dan Carl J. Dahlman, 2005. "The Knowledge Economy, the KAM Methodology and World Operations", Washington DC: the World Bank.

Dahlman, Carl J., Jorma Routti, and Pekka Yla-Anttila, 2006. Finland as a Knowledge Economy: Elements of Success and Lessons Learned, The Research institute of the Finnish Economy and the World Bank Institute.
GATS, GATS - Fact and Fiction, Geneva: WTO.

Suma Chitnis and Philip G. Altbach (eds), (1993) Higher Education Reform in India: Experiences and Perspectives, New Delhi:Sage Publications.

The Future Project: Policy for Higher Education in a Changing World, 2000. "The Universal Impact of Competition. and Globalization in Higher Education", Rhode Island: Brown University.

Undang-undang No. 14 Tahun 2005 tentang Guru dan Dosen

Undang-undang No. 20 Tahun 2003 tentang Sistem Pendidikan Nasional (Sisdiknas)

World Bank, 2003. "EFA in Indonesia: Hard Lessons About Quality".

World Bank, 2003. Indonesia's Education for All, Washington DC: the World Bank. 